\title{
THE PERICOPID GENUS COMPOSIA (Lepidoptera)
}

By Marston Bates, Museum of Comparative Zoology, Cambridge, Mass.

\section{Genus COMPOSIA Hübner}

Hübner, Ver. bek. Schm., p. 179 (1822). Genotype, Bombyx credula Fabricius, sole species.

Forbes (1930) has reviewed the two previously known forms of the genus, giving some bibliography that has not been repeated here.

Key to forms.

1. Hindwing with two rows of white spots on the disc, in addition to the submarginal row................................2. Hindwing immaculate except for the submarginal row of white spots 3.

2. Base of costa of forewing above with three white spots, which do not extend below the radial vein....1. C. credula. Base of costa of forewing with a red triangular area, which reaches the cubital stem below.....2. C. utowana.

3. Costa of forewing above with three distinct red spots, limited as in credula. 3a. C. f. fidelissima. These spots usually in part confluent, the outer spot extending below the radial vein, across the cell.

3b. C. f. vagrans.

\section{Composia credula (Fabricius)}

Bombyx credula Fabricius, 1775, p. 584; id., 1793, p. 475.

[Phalaena] sybaris Cramer, Pap. Ex., I, p. 112, pl. 71, fig. E. (1775).

Composia credula Hübner, Verz. bek. Schm., p. 179 (1822) ; id., Samml. ex. Schm., II, pl. 188, 4 figs. (1819-1826). Composia sybaris Forbes, 1930, p. 40. 
There are eight specimens of this species in the Museum of Comparative Zoology from Hispaniola and Jamaica; they show no racial differences. Puerto Rican specimens are said to agree with these also.

\section{Composia utowana, n. sp.}

The front is black, with white lateral stripes; the palpus is black and white: the third joint proportionately smaller than in credula or fidelissima. The thorax is black with three transverse rows of small spots above: the first two rows yellow, the last white, in the male, only the first row yellow in the female; beneath, the white is more extensive. The legs are marked much as in fidelissima. The abdomen is blue, the anterior edge of each segment marked with white, which forms a complete transverse band, except for a narrow mid-dorsal interruption.

The wings are black, with most of the hindwing, and the base and a small area at the tip of the cell of the forewing, irridescent blue. A red patch on the forewing covers the base of the cell and the lower half of the costa; three rows of white spots on this wing are similar in number and position to the spots on fidelissima, but much larger, and there are three additional spots in the median area never found in that species. The three rows of white spots on the hindwing are arranged as in credula, but are larger and more irregular. The pattern of the upper surface is repeated below.

Holotype ( $\delta$ ), and allotype ( $q$ ), No. 16594, in the Museum of Comparative Zoology, from Mariguana Island, Bahamas, Feb. 25, 1933, T. Barbour and David Fairchild.

This lovely moth is named after Allison V. Armour's yacht, the Utowana: the means through which our knowledge of tropical island life in both hemispheres has been greatly enlarged.

\section{3a. Composia fidelissima fidelissima H. S.}

Composia fidelissima Herrich-Schäffer, 1866, p. 132; Gundlach, 1881, p. 250 ; Forbes, 1930, p. 41.

Phaloësia olympia Butler, 1871, p. 290. 
The seven specimens of this form in the M. C. Z. show a very constant wing pattern. They come from Habana and Cienfuegos, in Cuba. I have seen no Central or South American specimens, but a specimen from Swan Island agrees closely with those from Cuba.

\section{3b. Composia fidelissima vagrans, n. subsp.}

Composia fidelissima Dyar, 1890, p. 105.

Composia olympia French, 1890, p. 153.

Bahaman specimens of this species differ strikingly from Cuban individuals in the character of the red markings on the costa of the forewing. The two basal spots are usually confluent, and the outer spot is much elongated, with a branch directed posteriorly across the cell. In New Providence specimens, this cell mark is a broad band; in specimens from Andros Is., Berry Is. and Crooked Is., it is much narrowed, and in Watling specimens it becomes white, near the cubital vein at least. Florida specimens show all of these variations, and some even approach the typical Cuban race very closely, having no spur across the radial vein at all on the upper surface; below, however, a red spur reaches the cubital vein in all of the specimens before me.

Holotype ( 8 ) and allotype ( $q$ ) No. 16595 in the M. C. Z., from Nassau, New Providence, Dec. 31, 1931, Allison V. Armour Expedition. There are 12 paratypes from New Providence, Andros, Berry, Crooked and Watling Islands, dated Feb., Apr. and July. There are also 11 Florida specimens, which belong to this race, from Lake Worth, Key West, Coconut Grove and Miami, dated Mar., Nov. and Dec.

\section{Literature Cited}

Butler, A. G.

1871. Descriptions of some new species of Lepidoptera, chiefly from the collection of Mr. Wilson Saunders. Ann. Mag. Nat. Hist. (4) VIII, pp. 282-291. 
Cramer, P.

1775-1779. Papillons exotiques des trois parties du monde . . . Tome I. Amsterdam. $155+\mathrm{xxx}$ pp., $96 \mathrm{pls}$.

Dyar, H. G.

1890. Two species of Lepidoptera new to our lists. Ent. News, I, pp. 105-106.

Fabricius, J.

1775. Systema entomologiae . . F Flensburgi et Lipsiae. $28+832 \mathrm{pp}$.

1793. Entomologia systematica emendata et aucta. Tome III, pars. I. Hafniae, 487 pp. (Glossata).

Forbes, W. T. M.

1930. Heterocera or moths (excepting Noctuidae, Geometridae and Pyralidae). Sci. Surv. Porto Rico and the Virgin Is., XII, pt. 1, pp. 1-171, pl. I, II.

French, G. H.

1890. Another tropical species of Lepidoptera in Florida. Ent. News, I, pp. 153-154, 1 fig.

Gundlach, J.

1881. Contribucion a la entomologia cubana. Vol. I, Lepidoptera. Habana, $445+\mathrm{xxi}$ pp.

Huebner, J.

1816-1826. Verzeichniss bekannter Schmettlinge. Augsburg, $431+72$ pp.

1819-1826. Sammlung exotischer Schmetterlinge. Bd. II. Augsburg, 28 pp., 225 pls.

Herrich-Schäffer, G. A. W.

1866. Schmetterlinge aus Cuba. Correspbl. zool-min. Ver. Regensb., XX, pp. 103-109; 113-120; 130-136. 

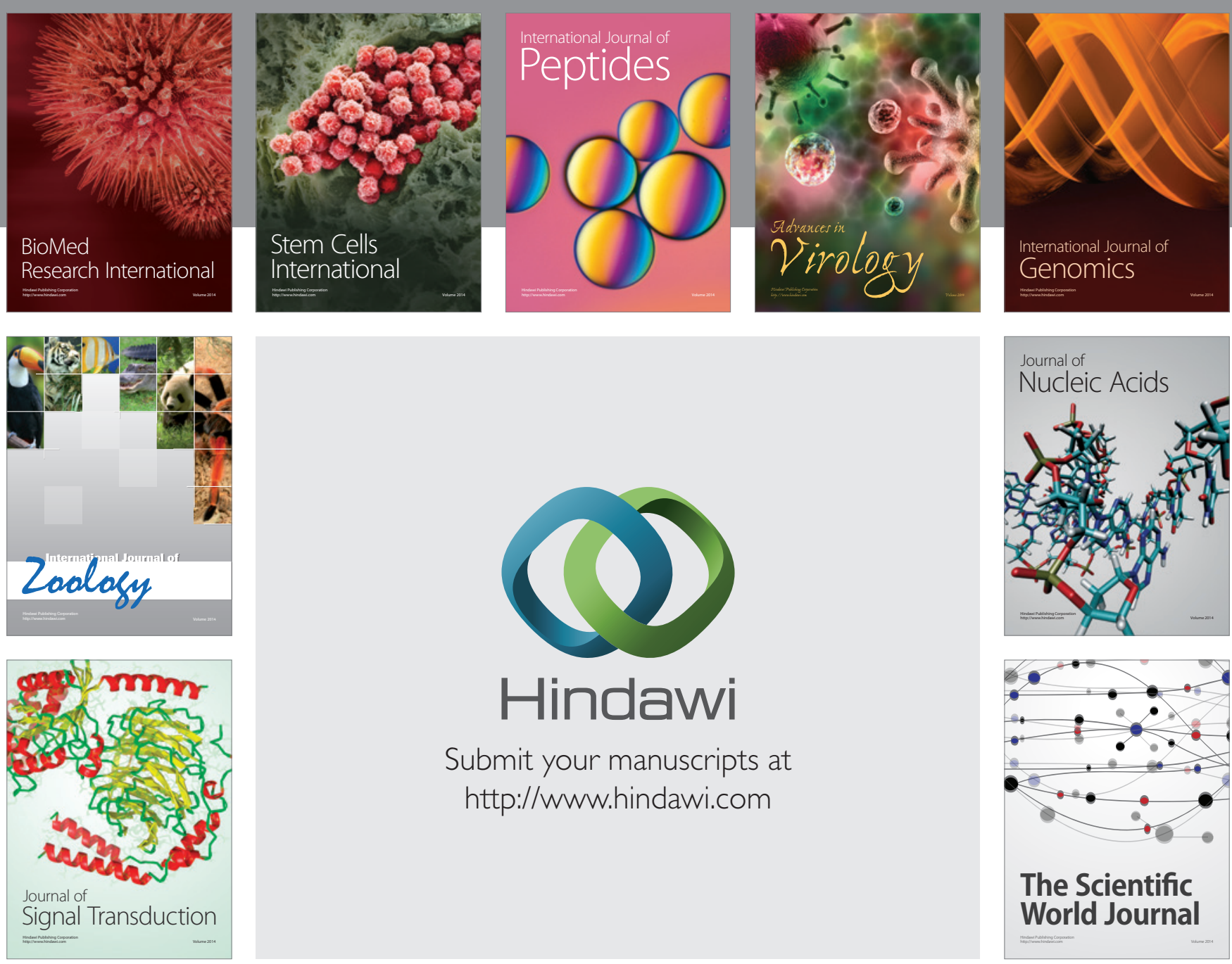

Submit your manuscripts at

http://www.hindawi.com
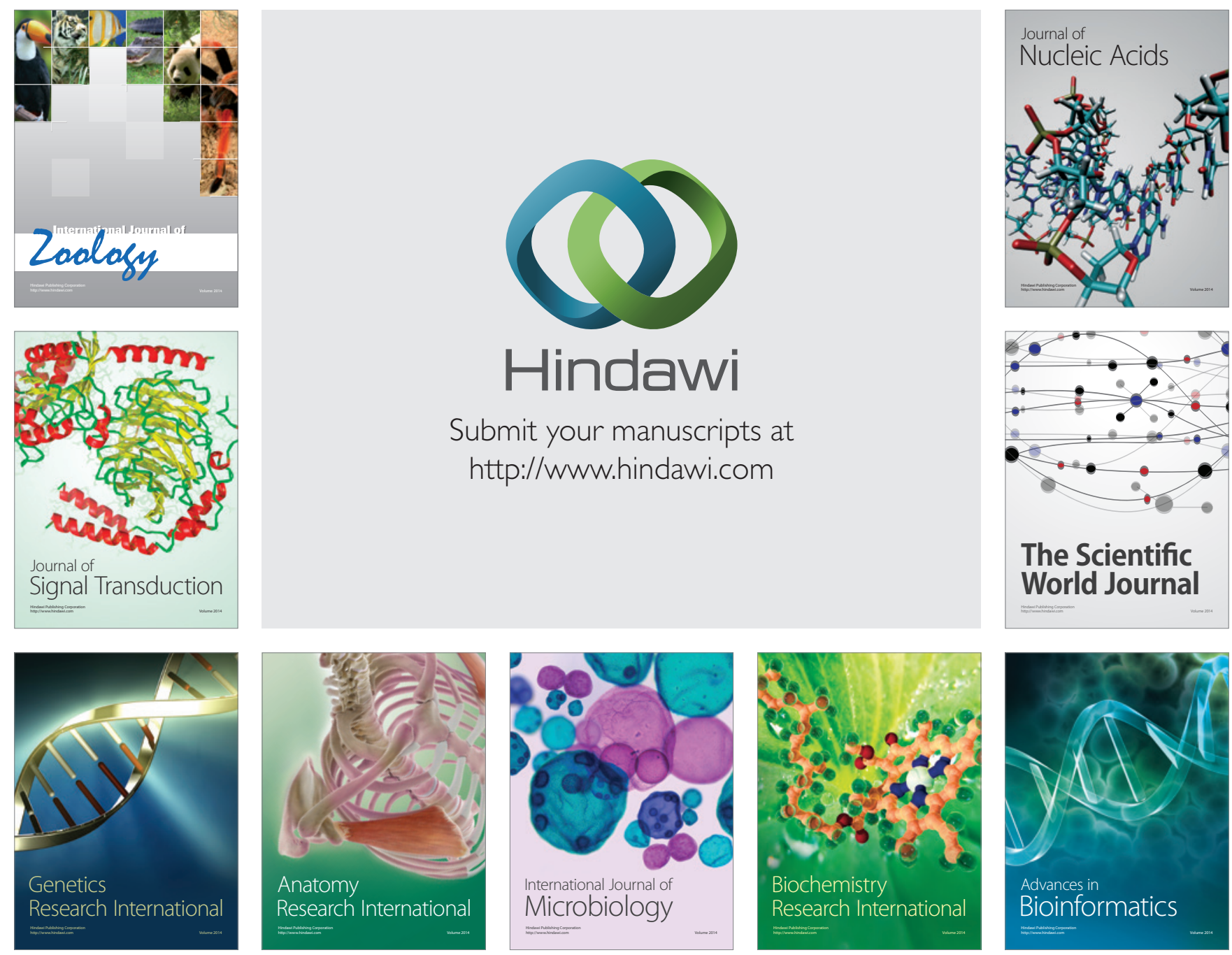

The Scientific World Journal
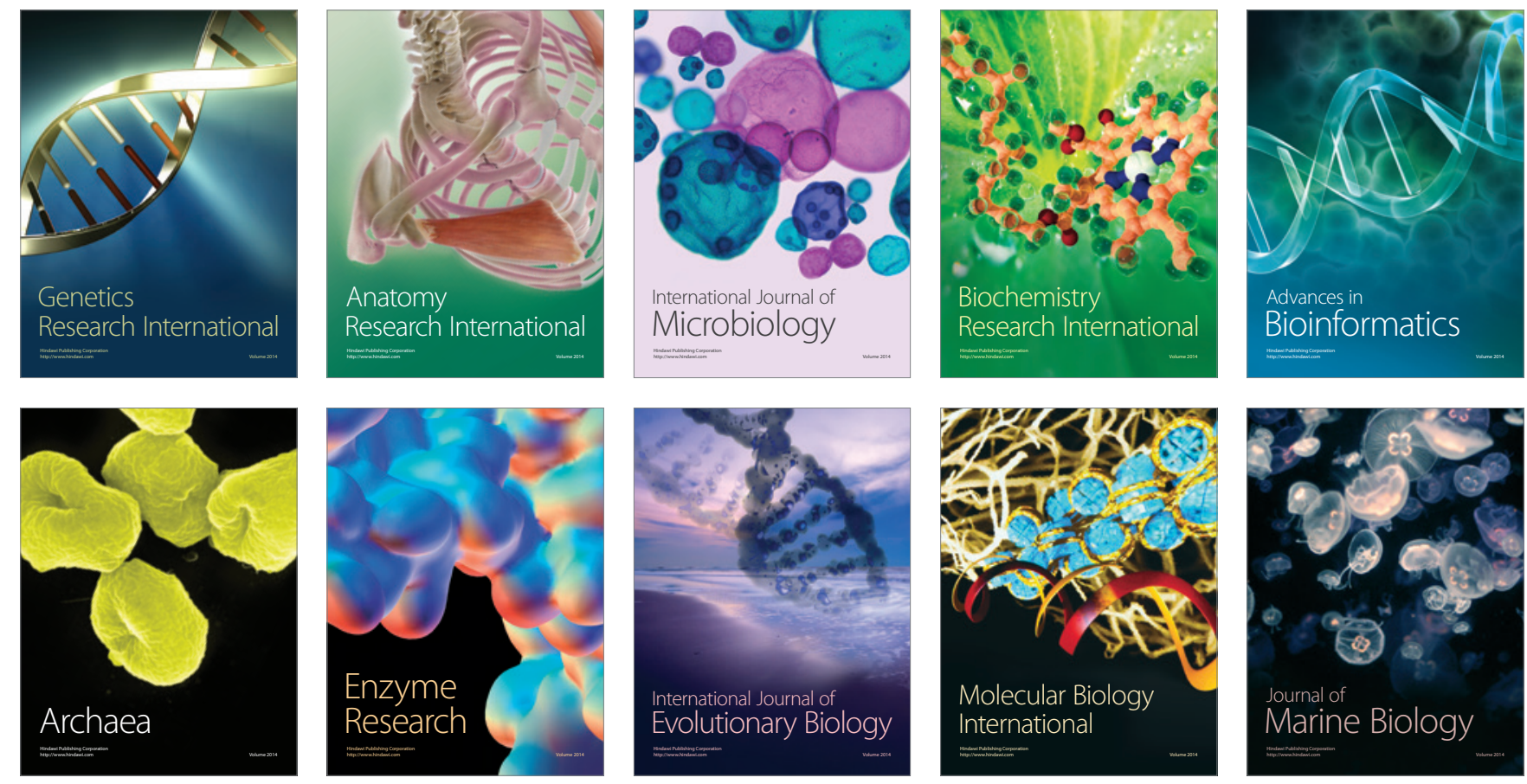